\title{
The multidirectional effects of insecticide-fungicide tank mix applications in maize protection
}

\author{
Wielokierunkowe działanie mieszanin insektycydowo-fungicydowych \\ w ochronie kukurydzy
}

\author{
Sławomir Drzewiecki, Barbara Krzyzińska, Joanna Pietryga
}

\begin{abstract}
Summary
In 2012-2013, studies were conducted to assess the effect of reducing the population of Ostrinia nubilalis Hübner using tank mixes of insecticides with a fungicide to control the causal agents of diseases affecting leaves and cobs of maize. The study used both pyrethroid and oxadiazine insecticides (Karate Zeon 050 CS and Steward 30 WG). The products were applied alone or in a tank mix with a fungicide containing pyraclostrobin and epoxiconazole (Retengo Plus $183 \mathrm{SE}$ ) at the time of onset (T1) and mass hatching (T2) of $O$. nubilalis caterpillars. The study found that an application of the insecticides and their mixes with the fungicide significantly decreased the number of $O$. nubilalis larvae in maize cobs and the number of damaged maize plants. Lower number of $O$. nubilalis larvae in maize cobs resulted in a significant reduction of maize cob area infected with the fungi from Fusarium genus and the mycotoxin content in maize grain.
\end{abstract}

Key words: insecticides; fungicides; Ostrinia nubilalis; Fusarium spp.; mycotoxin

\section{Streszczenie}

W latach 2012-2013 prowadzono badania, których celem była ocena wpływu redukcji populacji omacnicy prosowianki (Ostrinia nubilalis Hübner) na ograniczenie występowania sprawców chorób liści i kolb kukurydzy przez zastosowanie mieszanin insektycydów z fungicydem w uprawie kukurydzy. Zastosowano insektycydy z grupy pyretroidów i oksadiazyn (Karate Zeon 050 CS i Steward 30 WG). Środki aplikowano samodzielnie oraz w mieszaninach z fungicydem zawierającym piraklostrobinę i epoksykonazol (Retengo Plus 183 $\mathrm{SE}$ ), na początku (T1) oraz w czasie masowego wylęgu (T2) gąsienic omacnicy prosowianki. Stwierdzono istotne zmniejszenie liczebności larw omacnicy prosowianki w kolbach i mniejszy udział roślin uszkodzonych przez gąsienice po zastosowaniu insektycydów i mieszanin insektycydowo-fungicydowych. Ochrona insektycydowa przyczyniając się do zmniejszenia zasiedlenia kolb kukurydzy przez larwy 0 . nubilalis wpłynęła na istotne zmniejszenie porażenia powierzchni kolb kukurydzy przez grzyb rodzaju Fusarium oraz zawartości mikotoksyn w ziarnie.

Słowa kluczowe: insektycydy; fungicydy; Ostrinia nubilalis; Fusarium spp.; mikotoksyny

Instytut Ochrony Roślin - Państwowy Instytut Badawczy

Oddział Sośnicowice

Zakład Badania Skuteczności Środków Ochrony Roślin

Gliwicka 29, 44-153 Sośnicowice

s.drzewiecki@ior.gliwice.pl 


\section{Wstęp / Introduction}

Istotnymi czynnikami wpływającymi na plonowanie kukurydzy jest występowanie chorób i szkodników pojawiających się na plantacjach tej rośliny. W sprzyjających warunkach, choroby mogą przyczynić się do 20-30\% strat w plonach (Tekiela 2001). Według Tekieli (2005) do grzybów patogenicznych najczęściej zasiedlających uprawy kukurydzy w Polsce zaliczamy: Kabatiella zeae Naritia \& Hiratsuka, Setosphaeria turcica (Luttr.) K.J. Leonard \& Suggs oraz Fusarium spp. Za najgroźniejsze uważa się choroby powodowane przez ostatniego z omawianych sprawców, który jest przyczyną zgorzeli siewek, zgnilizny korzeni, zgorzeli podstawy łodygi, a przede wszystkim fuzariozy kolb. Występowanie grzybów rodzaju Fusarium wpływa na wzrost zawartości mikotoksyn w ziarnie kukurydzy (Nelson i wsp. 1993). Jednym z podstawowych czynników powodujących nasilenie symptomów chorób w łanie kukurydzy są uszkodzenia tkanek roślin spowodowane przez szkodniki, a szczególnie omacnicę prosowiankę (Ostrinia nubilalis Hübner), mającą największe znaczenie gospodarcze w środkowej i południowej części Europy (Welling 1989; Saladini i wsp. 2008). Owad ten jest również rozprzestrzeniony na terenie Polski stanowiąc największe zagrożenie spośród szkodliwej entomofauny zasiedlającej uprawy kukurydzy (Bereś i Konefał 2010). W latach sprzyjających znacznemu nasileniu omacnicy prosowianki gąsienice motyla mogą uszkadzać ponad 90\% roślin kukurydzy (Lisowicz 2003).

Celem badań była ocena wpływu redukcji populacji omacnicy prosowianki na ograniczenie występowania sprawców chorób liści i kolb kukurydzy przez zastosowanie mieszanin insektycydów z fungicydem w uprawie kukurydzy. W badaniach określono również wpływ zastosowanej ochrony na wielkość i jakość plonu ziarna kukurydzy.

\section{Materiały i metody / Materials and methods}

W latach 2012-2013 w Oddziale Instytutu Ochrony Roślin - Państwowego Instytutu Badawczego (IOR-PIB) w Sośnicowicach prowadzono badania w uprawie kukurydzy odmiany Kajfus (2012) i Amadeo (2013). W pierwszym roku doświadczenie założono w miejscowości Sławików, województwo śląskie (współrzędne geograficzne: szerokość 50.185884, długość 18.212300). W następnym roku obszar uprawy przeznaczony do badań znajdował się w miejscowości Słupsko, województwo śląskie (współrzędne geograficzne: szerokość 50.418257, długość 18.496207). Jednoczynnikowe doświadczenia zakładano na poletkach o powierzchni $25 \mathrm{~m}^{2} \mathrm{w}$ układzie bloków losowanych, w 4 powtórzeniach. Zastosowano insektycydy z grupy pyretroidów i oksadiazyn, charakteryzujące się kontaktowym i żołądkowym sposobem działania (lambdacyhalotryna, indoksakarb). Komponentem mieszanin był fungicyd zawierający piraklostrobinę i epoksykonazol (Retengo Plus 183 SE). Insektycydy, jak i fungicydy aplikowano samodzielnie oraz $\mathrm{w}$ mieszaninach. W badaniach uwzględniono obiekty opryskiwane jednokrotnie oraz kombinacje doświadczalne chronione w dwóch terminach. Termin zabiegów opryskiwania ustalono na podstawie obserwacji dotyczących składania i rozwoju jaj. Pierwszą aplikację środków wykonano w czasie masowego składania jaj przez szkodnika, a jednocześnie początku wylęgu gąsienic motyli omacnicy prosowianki (T1). Kolejny zabieg przeprowadzono 8 dni później, w czasie masowego wylęgu larw (T2). Poszczególne obiekty doświadczenia przedstawiono $\mathrm{w}$ tabelach $1-4$ uwzględniając dawkę zastosowanych środków oraz termin aplikacji.

Obserwacja wykonana w fazie mlecznej dojrzałości ziarniaków kukurydzy (BBCH 73-75) uwzględniała liczebność larw w kolbach oraz procent roślin uszkodzonych przez larwy omacnicy prosowianki. W tym celu z każdego poletka pobrano po 25 roślin ze środkowych rzędów.

Nasilenie chorób oceniano na podstawie porażenia powierzchni liści kukurydzy przez sprawców chorób w fazie pełni dojrzałości woskowej (BBCH 85), w tej samej fazie określano także zachowaną powierzchnię asymilacyjną liści kukurydzy. W fazie dojrzałości pełnej (BBCH 87-89) oznaczano porażenie powierzchni kolb przez grzyby rodzaju Fusarium. W Zakładzie Badania Środków Ochrony Roślin IOR-PIB w Poznaniu określono zawartość zearalenonu (ZEA) w ziarnie kukurydzy metodą HPLCDAD (High-Performance Liquid Chromatography with Diode-Array Detection). Oceniano także plon ziarna kukurydzy przeliczony na stałą wilgotność $14 \%$.

Wyniki poddano analizie statystycznej. Przy pomocy programu Statistica, wersja 8.0, wyliczono analizę wariancji ANOVA. Wyniki porównano za pomocą testu statystycznego Duncana na poziomie istotności $p=0,05$. W celu stwierdzenia zależności występujących między wybranymi zmiennymi wykonano analizę korelacji liniowej Pearsona.

\section{Wyniki i dyskusja / Results and discussion}

Podczas obserwacji stwierdzono, że średni procent roślin uszkodzonych przez larwy badanego gatunku w obiekcie kontrolnym wyniósł $76 \%$ (tab. 1). Wykazane różnice $\mathrm{w}$ procencie roślin uszkodzonych pomiędzy obiektami badanymi a kontrolą i obiektami niechronionymi insektycydami były statystycznie istotne. Odnotowano również istotne różnice pomiędzy kombinacjami z dwukrotnym zastosowaniem mieszanin insektycydowofungicydowych w porównaniu do obiektów chronionych środkami owadobójczymi jednokrotnie. W kombinacjach opryskiwanych jednokrotnie wyłącznie fungicydem w terminie T1 lub T2 odnotowano odpowiednio 55 i $62 \%$ roślin uszkodzonych przez larwy omacnicy. W wielu badaniach prezentowano wysoką skuteczność insektycydów wobec gąsienic omacnicy prosowianki i uzyskiwano istotnie mniejszy procent roślin $\mathrm{z}$ widocznymi śladami żerowania szkodnika po ich zastosowaniu w samodzielnym zabiegu (Bereś 2006; Drzewiecki i Pietryga 2007; Folcher i wsp. 2009). Procent roślin uszkodzonych przez larwy omacnicy po zastosowaniu insektycydu zawierającego indoksakarb, aplikowanego rozdzielnie oraz łącznie $\mathrm{z}$ fungicydem w terminie T2 wyniósł odpowiednio 12 i $6 \%$. Zabiegi te skuteczniej ograniczały uszkodzenia roślin kukurydzy $\mathrm{w}$ porównaniu do kombinacji $\mathrm{z}$ insektycydem zawiera- 
jącym lambda-cyhalotrynę w rozdzielnym zabiegu (21\%) i jego mieszaniny $\mathrm{z}$ fungicydem (20\%) zastosowanych w terminie T1. Najmniejszy udział uszkodzonych roślin w doświadczeniu odnotowano w kombinacjach, w których zastosowano dwukrotny zabieg insektycydem (T1: lambda-cyhalotryna, T2: indoksakarb) lub też dwuskładnikową mieszaninę (T1: lambda-cyhalotryna + fungicyd, T2: indoksakarb + fungicyd), odpowiednio 5 i $3 \%$. W badaniach prowadzonych w południowo-wschodniej Polsce, największą efektywność zwalczania larw omacnicy prosowianki Lisowicz i Jaworski (2000) odnotowali po dwukrotnym zastosowaniu insektycydu zawierającego lambda-cyhalotrynę.

W czasie oceny dotyczącej uszkodzeń roślin na skutek żerowania larw omacnicy prosowianki określono również liczebność gąsienic motyla w kolbach. Średnia liczebność larw szkodnika w kontroli wyniosła 0,6 szt. w kolbie. Średnia liczebność gąsienic w kombinacjach chronionych wyłącznie fungicydem była istotnie mniejsza niż na kontroli i wahała się w granicach $0,4-0,49$ szt. w zależności od terminu zabiegu. W efekcie dwukrotnego zastosowania fungicydu w terminach T1 i T2 stwierdzono średnio 0,15 szt. larw żerujących w generatywnej części roślin. Obserwacje te są zbieżne $\mathrm{z}$ wynikami badań Mazzoni i wsp. (2011), którzy stwierdzili mniejszą liczebność larw w kolbach kukurydzy po jednokrotnym (T1) i dwukrotnym (T1 + T2) zastosowaniu fungicydu w odniesieniu do kontroli. W obiektach, w których zastosowano insektycyd zawierający lambda-cyhalotrynę lub indoksakarb, jak również mieszaniny wyżej wymienionych substancji czynnych z fungicydem, stwierdzono 0,11-0,13 i 0,09-0,07 szt. larw, odpowiednio w terminie T1 i T2. Podobne wyniki uzyskała Tekiela i wsp. (2005) realizując badania dotyczące zwalczania larw omacnicy prosowianki, jak również innych szkodników kukurydzy. Badania prowadzone przez Folchera i wsp. (2009) wykazały również istotną redukcję liczebności larw w roślinie po aplikacji insektycydu, jak i środka owadobójczego w mieszaninie z fungicydem. Mazzoni i wsp. (2011) w swoich badaniach uzyskali redukcję liczebności larw omacnicy prosowianki w kolbach, w obiektach chronionych insektycydem oraz mieszaniną insektycydowo-fungicydową odpowiednio do poziomu 1,8 szt. i 2,3-2,6 szt. przy średniej liczebności w kontroli wynoszącej 4,6 szt. larw w kolbie kukurydzy. W badaniach własnych, w kombinacjach które były dwukrotnie opryskiwane zarówno poszczególnymi insektycydami, jak i ich mieszaninami $\mathrm{z}$ fungicydem stwierdzono pojedyncze larwy motyli. Średnia liczebność larw szkodnika w tych obiektach wyniosła 0,01 szt. w kolbie (tab. 1).

Zastosowanie ochrony, zarówno fungicydowej, jak i insektycydowej, samodzielnie lub łącznie, przyczyniło się do ograniczenia porażenia liści kukurydzy przez sprawcę żółtej plamistości oraz zachowania większej, średnio o 13,33-26,67 pkt. \% niż na kontroli powierzchni asymilacyjnej liści (tab. 2). W przypadku grzyba $K$. zeae taką zależność obserwowano tylko po zastosowaniu fungicydów i mieszanin insektycydowo-fungicydowych oraz po samodzielnym, dwukrotnym zastosowaniu środka owadobójczego. Istotnie najlepszą efektywność działania w zwalczaniu sprawców chorób liści kukurydzy obserwowano w kombinacjach doświadczalnych, w których jednym ze składników była mieszanina epoksykonazolu i piraklostrobiny. Pozytywny efekt w zwalczaniu grzyba $S$. turcica obserwował także Blandino i wsp. (2012) po zastosowaniu mieszaniny strobiluriny i triazolu.

Tabela 1. Wpływ zabiegów opryskiwania na uszkodzenia roślin spowodowane przez larwy omacnicy prosowianki oraz liczebność larw w kolbach kukurydzy - średnia z lat 2012-2013

Table 1. Effect of agrochemical treatments on ECB incidence and number of larvae in maize ears - the average of the years 2012-2013

\begin{tabular}{|c|c|c|c|}
\hline $\begin{array}{l}\text { Kombinacje doświadczalne } \\
\text { Treatments }\end{array}$ & $\begin{array}{l}\text { Dawka na ha } \\
\text { Dose per ha }\end{array}$ & $\begin{array}{c}\text { Średnia liczba larw } \\
\text { [szt./kolby] } \\
\text { Mean number } \\
\text { of caterpillars } \\
\text { [pcs per ear] }\end{array}$ & $\begin{array}{c}\text { Rośliny uszkodzone } \\
\text { Damaged plants } \\
{[\%]}\end{array}$ \\
\hline Kontrola - Untreated & - & $0,60 \mathrm{a}$ & $76 \mathrm{a}$ \\
\hline T1: lambda-cyhalothrin & T1: 0,21 & $0,11 \mathrm{~cd}$ & $21 \mathrm{c}$ \\
\hline T1: epoxiconazole + pyraclostrobin & T1: 1,51 & $0,40 \mathrm{~b}$ & $62 \mathrm{~b}$ \\
\hline T1: lambda-cyhalothrin; epoxiconazole + pyraclostrobin & T1: $0,21+1,51$ & $0,13 \mathrm{c}$ & $20 \mathrm{c}$ \\
\hline T2: indoxacarb & T2: $0,15 \mathrm{~kg}$ & $0,09 \mathrm{~cd}$ & $12 \mathrm{~d}$ \\
\hline T2: epoxiconazole + pyraclostrobin & $\mathrm{T} 2: 1,51$ & $0,49 \mathrm{~b}$ & $55 \mathrm{~b}$ \\
\hline T2: indoxacarb; epoxiconazole + pyraclostrobin & $\mathrm{T} 2: 0,15 \mathrm{~kg}+1,5 \mathrm{l}$ & $0,07 \mathrm{~cd}$ & $6 \mathrm{de}$ \\
\hline $\begin{array}{l}\text { T1: lambda-cyhalothrin } \\
\text { T2: indoxacarb }\end{array}$ & $\begin{array}{l}\text { T1: } 0,21 \text {; } \\
\text { T2: } 0,15 \mathrm{~kg}\end{array}$ & $0,01 \mathrm{~d}$ & $5 \mathrm{de}$ \\
\hline $\begin{array}{l}\text { T1: epoxiconazole }+ \text { pyraclostrobin } \\
\text { T2: epoxiconazole }+ \text { pyraclostrobin }\end{array}$ & $\begin{array}{l}\text { T1: } 1,51 \\
\text { T2: } 1,51\end{array}$ & $0,15 \mathrm{c}$ & $23 \mathrm{c}$ \\
\hline $\begin{array}{l}\text { T1: lambda-cyhalothrin; epoxiconazole + pyraclostrobin } \\
\text { T2: indoxacarb; epoxiconazole + pyraclostrobin }\end{array}$ & $\begin{array}{l}\text { T1: } 0,21+1,51 \\
\text { T2: } 0,15 \mathrm{~kg}+1,51\end{array}$ & $0,01 \mathrm{~d}$ & $3 \mathrm{e}$ \\
\hline
\end{tabular}

Wartości w kolumnach oznaczone tą samą literą nie różnią się istotnie - Values followed by the same letter are not significantly different 
Tabela 2. Wpływ zabiegów opryskiwania na porażenie liści kukurydzy przez sprawców chorób oraz zachowaną powierzchnię asymilacyjną liści - średnia z lat 2012-2013

Table 2. Effect of agrochemical treatments on infection of maize leaves by fungal diseases and green leaf area - the average of the years 2012-2013

\begin{tabular}{l|c|c|c|c}
\hline \multicolumn{1}{c|}{$\begin{array}{c}\text { Kombinacje doświadczalne } \\
\text { Treatments }\end{array}$} & Dawka na ha & $\begin{array}{c}\text { Setosphaeria } \\
\text { turcica }\end{array}$ & $\begin{array}{c}\text { Kabatiella } \\
\text { zeae }\end{array}$ & GLA* per ha \\
\cline { 3 - 5 } & & $\begin{array}{c}\text { \% porażonej powierzchni liści } \\
\% \text { of infected leaf area }\end{array}$ & $\begin{array}{c}\text { \% powierzchni } \\
\% \text { area }\end{array}$ \\
\hline Kontrola - Untreated & - & $18,83 \mathrm{a}$ & $24,33 \mathrm{a}$ & $47,50 \mathrm{~d}$ \\
\hline T1: lambda-cyhalothrin & $\mathrm{T} 1: 0,21$ & $13,00 \mathrm{~b}$ & $19,67 \mathrm{ab}$ & $60,83 \mathrm{c}$ \\
\hline T1: epoxiconazole + pyraclostrobin & $\mathrm{T} 1: 1,51$ & $7,50 \mathrm{c}$ & $14,00 \mathrm{cde}$ & $61,67 \mathrm{bc}$ \\
\hline T1: lambda-cyhalothrin; epoxiconazole + pyraclostrobin & $\mathrm{T} 1: 0,21+1,51$ & $7,33 \mathrm{c}$ & $15,00 \mathrm{~b}-\mathrm{e}$ & $68,00 \mathrm{abc}$ \\
\hline T2: indoxacarb & $\mathrm{T} 2: 0,15 \mathrm{~kg}$ & $12,67 \mathrm{~b}$ & $20,33 \mathrm{ab}$ & $72,67 \mathrm{ab}$ \\
\hline T2: epoxiconazole + pyraclostrobin & $\mathrm{T} 2: 1,51$ & $7,50 \mathrm{c}$ & $17,00 \mathrm{bc}$ & $60,83 \mathrm{c}$ \\
\hline T2: indoxacarb; epoxiconazole + pyraclostrobin & $\mathrm{T} 2: 0,15 \mathrm{~kg}+1,51$ & $6,50 \mathrm{c}$ & $14,00 \mathrm{cde}$ & $73,83 \mathrm{a}$ \\
\hline $\begin{array}{l}\text { T1: lambda-cyhalothrin } \\
\text { T2: indoxacarb }\end{array}$ & $\begin{array}{c}\mathrm{T} 1: 0,21 \\
\mathrm{~T} 2: 0,15 \mathrm{~kg}\end{array}$ & $12,83 \mathrm{~b}$ & $16,67 \mathrm{bcd}$ & $74,17 \mathrm{a}$ \\
\hline $\begin{array}{l}\text { T1: epoxiconazole + pyraclostrobin } \\
\text { T2: epoxiconazole + pyraclostrobin }\end{array}$ & $\begin{array}{c}\mathrm{T} 1: 1,51 \\
\mathrm{~T} 2: 1,51\end{array}$ & $5,33 \mathrm{c}$ & $11,33 \mathrm{de}$ & $65,00 \mathrm{abc}$ \\
\hline $\begin{array}{l}\text { T1: lambda-cyhalothrin; epoxiconazole + pyraclostrobin } \\
\text { T2: indoxacarb; epoxiconazole + pyraclostrobin }\end{array}$ & $\mathrm{T} 1: 0,21+1,51$ & $6,17 \mathrm{c}$ & $10,67 \mathrm{e}$ & $73,50 \mathrm{a}$ \\
\hline
\end{tabular}

*GLA - zachowana powierzchnia asymilacyjna - green leaf area

Wartości w kolumnach oznaczone tą samą literą nie różnią się istotnie - Values followed by the same letter are not significantly different

Istotne zmniejszenie porażenia kolb kukurydzy przez grzyby rodzaju Fusarium stwierdzono jedynie po zastosowaniu insektycydu samodzielnie lub w połączeniu z fungicydem (tab. 3). Zabieg opryskiwania wykonany tylko za pomocą środka grzybobójczego nie przyniósł efektu w postaci istotnego ograniczenia porażenia kolb kukurydzy przez fuzariozę. Ponadto wykazano, że pora- żenie kolb kukurydzy przez grzyby rodzaju Fusarium było wprost proporcjonalne do liczby larw $O$. nubilalis zasiedlających kolby (współczynnik korelacji wyniósł $r=0,876$ ). Dodatnią korelację między wzrostem uszkodzeń roślin kukurydzy przez tego szkodnika a porażeniem przez Fusarium spp. wykazał także Szulc (2013).

Tabela 3. Wpływ zabiegów opryskiwania na porażenie kolb kukurydzy przez grzyby rodzaju Fusarium oraz zawartość zearalenonu [ZEA] w ziarnie kukurydzy - średnia z lat 2012-2013

Table 3. Effect of agrochemical treatments on infection of maize ears by Fusarium spp. and content of zearalenone [ZEA] in kernels the average of the years 2012-2013

\begin{tabular}{|c|c|c|c|c|}
\hline \multirow[b]{2}{*}{$\begin{array}{c}\text { Kombinacje doświadczalne } \\
\text { Treatments }\end{array}$} & \multirow[b]{2}{*}{$\begin{array}{l}\text { Dawka na ha } \\
\text { Dose per ha }\end{array}$} & \multirow[b]{2}{*}{$\begin{array}{c}\text { Fusarium spp. } \\
\text { [\% porażonej } \\
\text { powierzchni } \\
\text { kolb] } \\
\text { [\% of infected } \\
\text { leaf cobs }]\end{array}$} & \multicolumn{2}{|c|}{$\begin{array}{l}\text { Zawartość ZEA } \\
\text { Content of ZEA }\end{array}$} \\
\hline & & & $\begin{array}{c}{[\mu \mathrm{g} / \mathrm{kg} \text { ziarna }]} \\
{[\mu \mathrm{g} / \mathrm{kg} \text { seeds }]}\end{array}$ & $\begin{array}{c}\text { redukcja } \\
\text { w stosunku } \\
\text { do kontroli } \\
\text { reduction } \\
\text { as compared } \\
\text { to control } \\
{[\%]}\end{array}$ \\
\hline Kontrola - Untreated & - & $7,42 \mathrm{a}$ & $101,00 \mathrm{a}$ & 0,00 \\
\hline T1: lambda-cyhalothrin & $\mathrm{T} 1: 0,21$ & $3,6 \mathrm{~b}-\mathrm{e}$ & $36,00 \mathrm{e}$ & 64,00 \\
\hline T1: epoxiconazole + pyraclostrobin & $\mathrm{T} 1: 1,51$ & $6,1 \mathrm{ab}$ & $86,25 \mathrm{~b}$ & 15,00 \\
\hline T1: lambda-cyhalothrin; epoxiconazole + pyraclostrobin & $\mathrm{T} 1: 0,21+1,51$ & $4,51 \mathrm{~b}-\mathrm{e}$ & $40,00 \mathrm{e}$ & 60,00 \\
\hline T2: indoxacarb & $\mathrm{T} 2: 0,15 \mathrm{~kg}$ & $2,53 \mathrm{de}$ & $20,75 \mathrm{fg}$ & 79,00 \\
\hline T2: epoxiconazole + pyraclostrobin & $\mathrm{T} 2: 1,51$ & $5,24 \mathrm{a}-\mathrm{d}$ & $58,00 \mathrm{c}$ & 43,00 \\
\hline T2: indoxacarb; epoxiconazole + pyraclostrobin & $\mathrm{T} 2: 0,15 \mathrm{~kg}+1,5 \mathrm{l}$ & $3,6 \mathrm{~b}-\mathrm{e}$ & $23,00 \mathrm{fg}$ & 77,00 \\
\hline $\begin{array}{l}\text { T1: lambda-cyhalothrin } \\
\text { T2: indoxacarb }\end{array}$ & $\begin{array}{c}\text { T1: } 0,21 \\
\text { T2: } 0,15 \mathrm{~kg}\end{array}$ & 2,84 cde & $27,75 \mathrm{f}$ & 73,00 \\
\hline $\begin{array}{l}\mathrm{T} 1 \text { : epoxiconazole }+ \text { pyraclostrobin } \\
\mathrm{T} 2 \text { : epoxiconazole }+ \text { pyraclostrobin }\end{array}$ & $\begin{array}{l}\text { T1: } 1,51 ; \\
\mathrm{T} 2: 1,51\end{array}$ & 5,46 abc & $49,75 \mathrm{~d}$ & 51,00 \\
\hline
\end{tabular}


Tabela 4. Wpływ zabiegów opryskiwania na plon ziarna kukurydzy - średnia z lat 2012-2013

Table 4. Effect of agrochemical treatments on grain yield of maize - the average of the years 2012-2013

\begin{tabular}{|c|c|c|c|}
\hline \multirow[b]{2}{*}{$\begin{array}{l}\text { Kombinacje doświadczalne } \\
\text { Treatments }\end{array}$} & \multirow[b]{2}{*}{$\begin{array}{l}\text { Dawka na ha } \\
\text { Dose per ha }\end{array}$} & \multicolumn{2}{|c|}{$\begin{array}{l}\text { Plon ziarna } \\
\text { Grain yield }\end{array}$} \\
\hline & & [t/ha] & $\begin{array}{c}\text { wzrost w stosunku } \\
\text { do kontroli } \\
\text { increase as compared } \\
\text { to control } \\
{[\%]}\end{array}$ \\
\hline Kontrola - Untreated & - & $10,54 \mathrm{~d}$ & 100 \\
\hline T1: lambda-cyhalothrin & T1: 0,21 & $12,74 \mathrm{ab}$ & 121 \\
\hline T1: epoxiconazole + pyraclostrobin & $\mathrm{T} 1: 1,51$ & $12,00 \mathrm{bc}$ & 114 \\
\hline T1: lambda-cyhalothrin; epoxiconazole + pyraclostrobin & T1: $0,21+1,51$ & $12,83 \mathrm{ab}$ & 122 \\
\hline T2: indoxacarb & $\mathrm{T} 2: 0,15 \mathrm{~kg}$ & $13,02 \mathrm{ab}$ & 124 \\
\hline T2: epoxiconazole + pyraclostrobin & $\mathrm{T} 2: 1,51$ & $11,52 \mathrm{c}$ & 109 \\
\hline T2: indoxacarb; epoxiconazole + pyraclostrobin & $\mathrm{T} 2: 0,15 \mathrm{~kg}+1,51$ & $13,25 \mathrm{a}$ & 126 \\
\hline $\begin{array}{l}\text { T1: lambda-cyhalothrin } \\
\text { T2: indoxacarb }\end{array}$ & $\begin{array}{l}\text { T1: } 0,21 \\
\text { T2: } 0,15 \mathrm{~kg}\end{array}$ & $13,30 \mathrm{a}$ & 126 \\
\hline $\begin{array}{l}\text { T1: epoxiconazole }+ \text { pyraclostrobin } \\
\text { T2: epoxiconazole + pyraclostrobin }\end{array}$ & $\begin{array}{l}\text { T1: } 1,51 \\
\text { T2: } 1,51\end{array}$ & $10,20 \mathrm{~d}$ & 97 \\
\hline $\begin{array}{l}\text { T1: lambda-cyhalothrin; epoxiconazole }+ \text { pyraclostrobin } \\
\text { T2: indoxacarb; epoxiconazole }+ \text { pyraclostrobin }\end{array}$ & $\begin{array}{l}\text { T1: } 0,21+1,51 \\
\text { T2: } 0,15 \mathrm{~kg}+1,51\end{array}$ & $13,04 \mathrm{ab}$ & 124 \\
\hline
\end{tabular}

Wartości w kolumnach oznaczone tą samą literą nie różnią się istotnie - Values followed by the same letter are not significantly different

Zastosowana ochrona wpłynęła również na zmniejszenie zawartości zearalenonu w ziarnie kukurydzy o 15-83 pkt. \% w stosunku do kontroli (tab. 3). Niezależnie od wyboru środka najlepszą efektywność przyniosło jednokrotne zastosowanie insektycydu w terminie T2 lub dwukrotne w terminie T1 i T2 samodzielnie, ale także w połączeniu $\mathrm{z}$ fungicydem (73-83 pkt. \%). Mniejszy spadek zawartości ZEA w ziarnie obserwowano po zastosowaniu środków owadobójczych w terminie T1 o 60-64 pkt. \%. Natomiast najsłabiej, zaledwie o $15 \%$ w stosunku do kontroli, ograniczyła zawartość tej mikotoksyny jednokrotna ochrona fungicydowa w terminie T1. W swoich badania Blandino i wsp. (2012) nie wykazali wpływu zastosowanych fungicydów na obniżenie stężenia mikotoksyn w ziarnie kukurydzy oraz porażenie kolb przez grzyby rodzaju Fusarium. W badaniach Tekieli i wsp. (2005) jedynie zabiegi insektycydowe ograniczyły stopień zasiedlenia kolb przez grzyby patogeniczne, a także pośrednio przyczyniły się do obniżenia zawartości zearalenonu i deoksyniwalenonu w ziarnie kukurydzy. Takich zależności nie odnotowali Saladini i wsp. (2008), natomiast badacze ci stwierdzili, że po ograniczeniu nasilenia występowania larw omacnicy prosowianki zawartość fumonizyny zmniejszyła się o $68 \%$ w stosunku do obiektu niechronionego.

Wzrost nasilenia występowania omacnicy prosowianki w uprawie kukurydzy w dużym stopniu wpływa na obniżenie plonu rośliny uprawnej (Bereś 2006). Największy wzrost plonu ziarna, na poziomie $26 \%$ wobec kontroli stwierdzono w kombinacjach opryskiwanych dwukrotnie badanymi insektycydami lub mieszaniną środka zawierającego indoksakarb $\mathrm{z}$ fungicydem zastosowaną w terminie T2 (tab. 4). Przyrost plonu ziarna, w stosunku do kontroli, w pozostałych obiektach $\mathrm{z}$ zastosowaniem insektycydu lub mieszanin z jego udziałem wzrósł średnio o 21-24\%. Efektem jednokrotnego zastosowania fungicydu był wzrost plonu ziarna w granicach 9-14\% w stosunku do kontroli, w zależności od terminu aplikacji. Nelson i Meinhardt (2011) wskazują, że środki grzybobójcze zawierające strobiluryny, nawet w przypadku braku porażenia kukurydzy przez sprawców chorób wpływają korzystnie na fizjologię roślin i powodują wzrost plonu ziarna.

\section{Wnioski / Conclusions}

1. Zabiegi ochronne, w których zastosowano samodzielnie lub łącznie fungicyd (piraklostrobina i epoksykonazol) i insektycydy (lambda-cyhalotryna, indoksakarb) ograniczyły porażenie liści kukurydzy przez grzyb $S$. turcica i tym samym wpłynęły na poprawę kondycji roślin.

2. Zastosowanie fungicydu epoksykonazol + piraklostrobina $w$ obu badanych terminach, jak również $\mathrm{w}$ połączeniu $\mathrm{z}$ zabiegiem insektycydowym istotnie ograniczało występowanie $K$. zeae. Najlepszy efekt osiągnięto stosując dwuzabiegowo ochronę fungicydowo-insektycydową.

3. Ograniczenie zasiedlenia kolb kukurydzy przez larwy omacnicy prosowianki poprzez zastosowanie ochrony insektycydowej lub fungicydowo-insektycydowej wpłynęło na istotne zmniejszenie porażenia powierzchni kolb kukurydzy przez grzyb rodzaju Fusarium oraz zawartości mikotoksyn w ziarnie.

4. Potwierdzono istotny wpływ zabiegów insektycydowych na zmniejszenie liczebności larw w kolbach i mniejszy udział roślin uszkodzonych przez gąsienice 
omacnicy prosowianki. Nie odnotowano statystycznie istotnych różnic dotyczących liczby larw w kolbach kukurydzy oraz procentu uszkodzonych roślin pomiędzy kombinacjami $\mathrm{z}$ samodzielnym zastosowaniem insektycydów a aplikacją mieszanin insektycydowofungicydowych w badanych terminach zabiegów.

5. Stwierdzono efektywniejsze działanie insektycydów $\mathrm{i}$ ich mieszanin $\mathrm{z}$ fungicydami aplikowanych $\mathrm{w}$ czasie masowego wylęgu larw (T2) w porównaniu do zabiegów w terminie T1, zarówno w odniesieniu do zmniejszenia liczby uszkodzonych roślin przez szkodnika, redukcji liczebności larw, jak i mniejszej zawartości zearalenonu w ziarnie kukurydzy.

6. Dwuletnie badania wykazały wpływ fungicydów na ograniczenie liczebności larw omacnicy prosowianki w porównaniu do obiektu niechronionego.

7. We wszystkich badanych obiektach, w których zastosowano ochronę insektycydową oraz insektycydowofungicydową wykazano wzrost plonu ziarna kukurydzy. Nie obserwowano statystycznie istotnych różnic pomiędzy jedno- lub dwukrotnym zastosowaniem insektycydów, jak też ich mieszanin z fungicydem.

\section{Literatura / References}

Bereś P. 2006. Efekty chemicznego zwalczania omacnicy prosowianki (Ostrinia nubilalis Hbn.) w południowo-wschodniej Polsce w latach 2003-2005. [Effects of chemical control of the European corn borer (Ostrinia nubilalis Hbn.) in south-eastern Poland in 2003-2005]. Prog. Plant Prot./Post. Ochr. Roślin 46 (2): 464-467.

Bereś P., Konefał T. 2010. Distribution range of the European corn borer (Ostrinia nubilalis Hbn.) on maize in 2004-2008 in Poland. J. Plant Prot. Res. 50 (3): 326-334.

Blandino M., Galeazzi M., Savoia W., Reyneri A. 2012. Timing of azoxystrobin + propiconazole application on maize to control northern corn leaf blight and maximize grain yield. Field Crops Res. 139: 20-29.

Drzewiecki S., Pietryga J. 2007. Zwalczanie ważniejszych szkodników w kukurydzy pastewnej insektycydem Proteus 110 OD. [Effectiveness of insecticide Proteus 110 OD (thiaclopride + deltamethrin) in the control of major corn pests]. Prog. Plant Prot./Post. Ochr. Roślin 47 (1): 209-217.

Folcher L., Jarry M., Weissenberger A., Gerault F., Eychenne N., Delos M., Regnault-Roger C. 2009. Comparative activity of agrochemical treatments on mycotoxin levels with regard to corn borers and Fusarium mycoflora in maize (Zea mays L.) fields. Crop Prot. 28: 302-308.

Lisowicz F. 2003. Narastająca szkodliwość omacnicy prosowianki (Ostrinia nubilalis Hbn.) dla kukurydzy w południowo-wschodniej Polsce. [Increasing harmfulness of European corn borer (Ostrinia nubilalis Hbn.) on maize in south-eastern Poland]. Prog. Plant Prot./Post. Ochr. Roślin 43 (1): 247-250.

Lisowicz F., Jaworowski S. 2000. Badania nad łącznym zwalczaniem mszyc (Aphididae), przylżeńców (Thysanoptera) i omacnicy prosowianki (Ostrinia nubilalis Hbn.) na kukurydzy. [Studies on combined control of aphids, thrips and European corn borer on maize]. Prog. Plant Prot./Post. Ochr. Roślin 40 (2): 492-494.

Mazzoni E., Scandolara A., Giorni P., Pietri A., Battilani P. 2011. Field control of Fusarium ear rot. Ostrinia nubilalis (Hübner) and fumonisin in maize kernels. Pest Manage. Sci. 67: 458-465.

Nelson P.E., Desjardins A.E., Plattner R.D. 1993. Fumonisins, mycotoxins produced by Fusarium species: biology, chemistry, and significance. Annu. Rev. Phytopathol. 31: 233-252.

Nelson K.A., Meinhardt C.G. 2011. Foliar boron and pyraclostrobin effects on corn. Agron. J. 103: 1352-1358.

Saladini M.A., Blandino M., Reyneri A., Alma A. 2008. The impact of insecticide treatments on Ostrinia nubilalis (Hübner) (Lepidoptera: Crambidae) and their influence on the mycotoxin contamination in maize kernels. Pest Manage. Sci. 64: 1170-1178.

Szulc P. 2013. Nawożenie organiczne i mineralne kukurydzy kształtujące występowanie chorób fuzaryjnych (Fusarium spp.) oraz omacnicy prosowanki Ostrinia nubilalis (Hbn.). [Organic and mineral fertilization of maize affecting prevalence of fusarium diseases (Fusarium spp.) and European corn borer (Ostrinia nubilalis Hbn.)]. Prog. Plant Prot./Post. Ochr. Roślin 53 (3): $498-502$.

Tekiela A. 2001. Najważniejsze choroby kukurydzy. Kukurydza rośliną przyszłości. Poradnik dla producentów. Agro Serwis: $29-31$.

Tekiela A. 2005. Występowanie i szkodliwość drobnej plamistości liści kukurydzy [Aureobasidium zeae (Narita et Hiratsuka) J.N. Dingley] i żółtej plamistości liści kukurydzy (Trichometasphaeria tarcica Luttr.) na kukurydzy w południowo-wschodniej Polsce. [The occurrence and economic importance of eyespot [Aureobasidium zeae (Narita et Hiratsuka) J.N. Dingley] and leaf spot (Trichometasphaeria tarcica Luttr.) of maize diseases in south-eastern Poland]. Prog. Plant Prot./Post. Ochr. Roślin 45 (1): 484-486.

Tekiela A., Bereś P., Grajewski J., Miklaszewska B. 2005. Wpływ zwalczania chorób i szkodników kukurydzy na zasiedlenie ziarna przez grzyby i zawartość mikotoksyn. [Influence of diseases and pests control on occurrence of fungi on grain and content of mycotoxins]. Prog. Plant Prot./Post. Ochr. Roślin 45 (2): 1149-1152.

Welling M. 1989. The appearance of different strains of the European corn borer in Germany. Acta Phytopathol. Entomol. Hung. 24 (1-2): 225-229. 